\title{
MICROSTRUCTURE AND MECHANICAL PROPERTIES OF STELLITE 6 ALLOY POWDERS INCORPORATED WITH Ti/B 4 C USING PLASMA-ARC-SURFACING PROCESSES
}

\section{MIKROSTRUKTURA IN MEHANSKE LASTNOSTI PRAHOV IZ ZLITINE STELLITE 6 Z DODATKOM Ti/B ${ }_{4} \mathrm{C}$ ZA OPLAŠČENJE S PLAZEMSKIM NAPRŠEVANJEM}

\author{
Zhi-Yuan Zhu $^{1 *}$, Chun Ouyang ${ }^{1}$, Jia-Huan Chen ${ }^{1}$, Yan-Xin Qiao ${ }^{1,2}$ \\ ${ }^{1}$ School of Materials Science and Engineering, Jiangsu University of Science and Technology, no. 2 Mengxi Road, Jingkou District, Zhenjiang \\ 212003, China \\ ${ }^{2}$ Shenzhen Institute, Peking University, no. 15, Gaoxin Nanqi Road, Nanshan District, Shenzhen 518057, China \\ Prejem rokopisa - received: 2018-03-14; sprejem za objavo - accepted for publication: 2018-08-23
}

doi:10.17222/mit.2018.044

Composite powders including $\mathrm{Ti}, \mathrm{B}_{4} \mathrm{C}$ and Stellite 6 were deposited on the 316 stainless steel using plasma-transferred arc welding to improve the wear resistance. Microstructural characterisation using an optical microscope and a Vickers hardness tester was performed on the surface to determine the coating and hardness. Scanning electron microscopy and energy-dispersive-spectroscopy line scanning were also applied to characterise the microstructure, the chemical composition and the process of wear. Results showed that Ti, $\mathrm{B}_{4} \mathrm{C}$ and Stellite 6 considerably affected the microstructure and morphology of the coating. The in-situ new phases, namely, TiC and TiB, remarkably improved the wear resistance compared with the Stellite 6 coating only.

Keywords: in-situ, microstructure, PTAW, wear resistance

Avtorji so kompozitne prahove iz zlitine Stellite 6, Ti in $\mathrm{B}_{4} \mathrm{C}$ nanašali na površino preizkušancev s plazemskim naprševanjem (PTAW), da bi izboljšali njihovo odpornost proti obrabi. Izvedli so mikrostrukturno in mehansko karakterizacijo površine z uporabo optičnega mikroskopa in Vickersovega merilnika trdote. Prav tako so izvedli preiskave z vrstičnim elektronskim mikroskopom (SEM) in linijsko energijsko disperzijsko spektroskopijo (EDS), da bi ugotovili mikrostrukturo, kemijsko sestavo in potek obrabe. Rezultati raziskav so pokazali, da so $\mathrm{Ti}, \mathrm{B}_{4} \mathrm{C}$ in Stellite 6 znatno vplivali na mikrostrukturo in morfologijo prevleke. In-situ sinteza novih faz (TiC in $\mathrm{TiB}$ ) med plazenskim naprševanjem kompozitnih prahov je močno izboljšala odpornost prevlek proti obrabi v primerjavi s prevlekami, izdelanimi samo iz prahu Stellita 6.

Ključne besede: in-situ sinteza novih faz, mikrostruktura, PTAW (plazemsko naprševanje), odpornost proti obrabi

\section{INTRODUCTION}

Wear consistently occurs as long as engineering components come in contact with one another, thus causing a component loss and local temperature increments. ${ }^{1,2}$ Wear reduces the components' strength and corrosion resistance and decreases their service life. ${ }^{3}$ Suitable metals with good hardness and wear-resistant coating are deposited on the matrix to resolve these problems. ${ }^{4}$ Hard coating alloys, such as Co-based ones, demonstrate excellent performance and are widely used in scientific research and industrial applications. ${ }^{5-7}$ Stellite 6 is a Co-based alloy that consists of complex carbides included in an alloy matrix. ${ }^{8}$ Co is resistant to wear, galling and corrosion at high temperatures. Stellite 6 is the most widely used wear-resistant Co-based alloy, exhibiting good performance. It is an industry standard for general-purpose wear-resistance applications, exhibiting excellent resistance to many forms of mechanical

*Corresponding authors e-mail:

salanganezhu@163.com (Zhiyuan Zhu),

oyc1014@163.com (Chun Ouyang) and chemical degradation. Stellite 6 also has good resistance to impact and cavitation erosion. It is adopted in many hardfacing processes and can be used with carbide tooling. Stellite 6 is an effective hardfacing alloy because Co exhibits good corrosion resistance, high strength and good wear resistance. The Mo and W formed with $\mathrm{C}$ affect the solid solution and precipitation-hardening phase to improve the strength of Stellite 6. ${ }^{9-11}$ Ceramic powders that contain N, C, B and Si are introduced into composite powders and combined with Stellite 6. ${ }^{5,12-15}$ Phases $\mathrm{B}_{4} \mathrm{C}$ and $\mathrm{TiB}_{2}$ provide a homogenous morphology and excellent mechanical properties. ${ }^{4}$ These ceramic particles improve the wear resistance of welding coatings. ${ }^{16,17} \mathrm{SiC}$ dispersed in the AISI 316L stainless steel has also been used to improve the wear resistance. Several techniques, such as gas tungsten arc welding (GTAW), ${ }^{18}$ plasma transferred arc welding (PTAW),${ }^{19}$ laser cladding, ${ }^{20}$ electric spark deposition $(E S D)^{21}$ and shielded metal arc welding (SMAW), ${ }^{22}$ are used for the surface modification of the hard faces of metal powders. PTAW has the advantages of high energy, controlled welding depth, high efficiency and excellent 
Table 1: Nominal chemical composition of Stellite $6(w / \%)$

\begin{tabular}{|c|c|c|c|c|c|c|c|c|c|}
\hline Composition & $\mathrm{C}$ & $\mathrm{Cr}$ & $\mathrm{Si}$ & $\mathrm{W}$ & $\mathrm{Fe}$ & $\mathrm{Mo}$ & $\mathrm{Ni}$ & $\mathrm{Mn}$ & Co \\
\hline Mass percent & 1.15 & 29.00 & 1.10 & 4.00 & 3.00 & 1.00 & 3.00 & 0.50 & Bal. \\
\hline
\end{tabular}

direction control and metallurgical bonding of the interface. ${ }^{23-25}$

Previous studies showed that delamination and abrasive wear can be observed by studying wear debris. In the present study, Stellite 6 and composite powders were used to prepare a welding coating. The composite powders consisted of $\mathrm{Ti}, \mathrm{B}_{4} \mathrm{C}$ and Stellite 6 . Our aim is to study the effect of these powders on the microstructure, hardness, friction coefficient and wear resistance of welding coatings. We maintain that these components and phases affect the wear resistance.

\section{EXPERIMENTAL PART}

\subsection{Materials and welding experiments}

In this study, the 316 stainless steel was used as the base material. Its composition $(w / \%)$ was $0.05 \mathrm{C}, 0.76$ Mn, 0.30 Si, 2.4 Mo, 12.2 Ni, 17.3 Cr, 0.015 P, 0.02 S and Fe balance. The Stellite 6 powder was utilised as a PTAW welding material. The composition of Stellite 6 is shown in Table 1. The composite powders consisted of $\mathrm{Ti}, \mathrm{B}_{4} \mathrm{C}$ and Stellite 6 . These powders were mixed using a ball mill. The composition of the mixed powder is indicated in Table 2. The mixed powder was pre-painted on the surface of the base metal. Prior to welding, the matrix surface was cleaned carefully with acetone to remove residues and grease. The powder was deposited onto the matrix, having a thickness of approximately $2 \mathrm{~mm}$. The welding coatings were prepared using PTAW with a current of $150 \mathrm{~A}$.

Table 2: Mass percent of the mixed powder $(w / \%)$

\begin{tabular}{|c|c|c|}
\hline $\mathrm{Ti}$ & $\mathrm{B}_{4} \mathrm{C}$ & Stellite 6 \\
\hline 10 & 3 & 87 \\
\hline
\end{tabular}

\subsection{Microstructural characterisation}

The coating material was cut along the perpendicular direction of the contact line of the substrate and coating. The surface cut was trapped with Bakelite and the sample was polished with abrasive paper down to \#1000. Subsequently, the surface of the sample was cleaned with acetone and etched with nitrohydrochloric acid. The surface images of the samples were obtained with a Zeiss Merlin compact field-emission scanning electron microscope (FE-SEM). An element analysis was performed on the spots or areas of the samples using energy dispersive spectroscopy (EDS). An X-ray diffraction (Bruker D8 ADVANCE) analysis was performed with $\mathrm{Cu} K_{\alpha}$ radiation. A step of $0.02^{\circ}$ was used to scan $2 \theta$ from $20^{\circ}$ to $90^{\circ}$.

\subsection{Vickers microhardness and properties of the wear resistance}

Vickers microhardness was measured with an MH-5 microhardness tester with five points of similar places under a load of $0.5 \mathrm{~kg}$. The test was repeated at least five times to ensure good reproductivity. Experiments on the wear resistance were conducted using a UMT-2 frictionwear tester (USA). Samples with a size of $(15 \times 15 \times$ 4) $\mathrm{mm}$ were extracted from the coating. The surfaces of the samples were polished to keep them horizontally parallel. Subsequently, the samples were ultrasonically cleaned in acetone. A tribological test was conducted using a ball-on-disc under a load of $10 \mathrm{~N}$. The test was conducted using the $\mathrm{C} 45$ spherical steel with a $9.38-\mathrm{mm}$ diameter (ASTM: 1045) at room temperature. The speed of the sample against the ball was maintained at $2.5 \mathrm{~cm} \mathrm{~s}^{-1}$ for $30 \mathrm{~min}$. After testing the wear resistance, the morphology of the wear track was examined with a
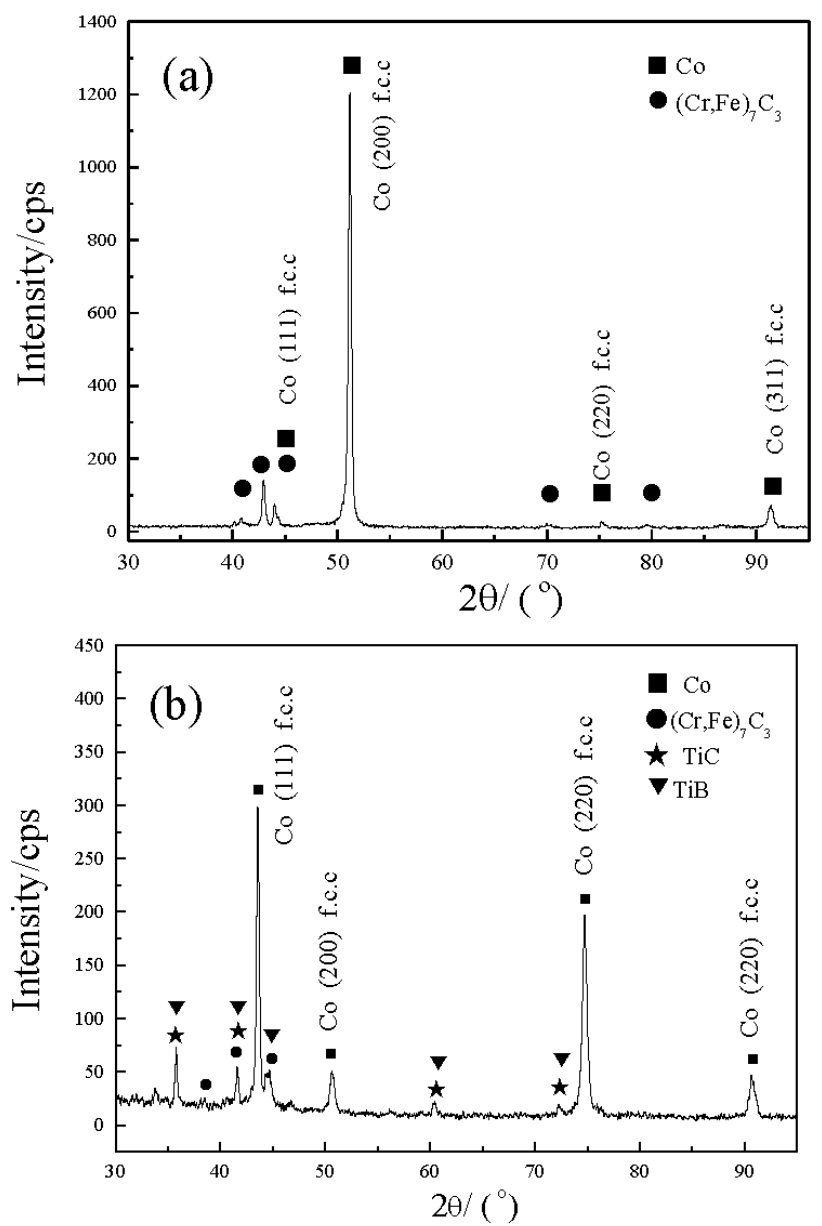

Figure 1: XRD patterns of the hardfacing layers produced with plasma arc surfacing: a) Stellite 6 powder coating and b) composite powder coating 
confocal laser scanner (LEXTOLS400). The wear rate was calculated as

$$
W_{\mathrm{s}}=\frac{C A}{F L}
$$

where $C$ is the length of the wear track, $A$ is the average area of wear loss, $F$ is the loading and $L$ is the distance of wear. After the experiments, the surfaces of the samples were characterised with SEM.

\section{RESULTS AND DISCUSSION}

\subsection{XRD and SEM/EDS characterisation}

The results of the X-ray diffraction analysis of the alloy coating with Stellite 6 and composite powders are shown in Figures 1a and 1b, respectively. The phases after the deposition of the composite powders were $\mathrm{Cr}_{23} \mathrm{C}_{6}, \mathrm{TiC}, \mathrm{TiB}, \mathrm{Cr}_{7} \mathrm{C}_{6}$ and $\alpha$-Co. The phases of the coating using the Stellite 6 powder were $\alpha$-Co and $\mathrm{Cr}_{7} \mathrm{C}_{3}$. The addition of $\mathrm{Ti}$ and $\mathrm{B}_{4} \mathrm{C}$ to the Stellite 6 powders changed the microstructure due to plasma surfacing.

SEM images of the Stellite 6 coating are shown in Figure 2. The XRD analysis from Figure 1a shows that the $\alpha$-Co phase formed dendrites and that interdendrites


Figure 2: SEM images of hardfacing of the Stellite 6 coating were composed of $(\mathrm{Cr} . \mathrm{Fe})_{7} \mathrm{C}_{3}{ }^{26,27}$ The hard phases, such as $(\mathrm{Fe}, \mathrm{Cr})_{7} \mathrm{C}_{3}$ and $\mathrm{TiC}$, generated with the addition of $\mathrm{Ti}$ and $\mathrm{B}_{4} \mathrm{C}$ using plasma arc surfacing, determined the hardness, strength, corrosion resistance and wear resistance at high temperatures.

A detailed microstructure of the coating with the composite powder on the surface is shown in Figure 3, where Figure 3a shows an optical image and Figure 3b shows a SEM image. This coating consisted of the $\alpha$-Co matrix and $\mathrm{TiC} / \mathrm{TiB}$ particles. Many particles smaller than $3 \mu \mathrm{m}$ were embedded in the $\alpha$-Co matrix. The solidification process of the coating followed the nonequilibrium process of PTAW. When the $\mathrm{Ti}$ and $\mathrm{B}_{4} \mathrm{C}$ powders were added to the Stellite 6 powder, the solidification process became increasingly complex. The melting points of $\mathrm{TiB}$ and $\mathrm{TiC}$ were $3498 \mathrm{~K}$ and $3340 \mathrm{~K}$, respectively. Freezing was observed initially, acting as the core of the heterogeneous nucleation during the solidification. Therefore, the in-situ phases of $\mathrm{TiB}$ and TiC were surrounded by other phases such as $\alpha$-Co and $(\mathrm{Fe}, \mathrm{Cr})_{7} \mathrm{C}_{3}$.

The concentrations of $\mathrm{C}, \mathrm{Ti}, \mathrm{Cr}, \mathrm{Fe}, \mathrm{Ni}$ and $\mathrm{W}$ varied considerably at the three analysed sites, as shown in Figure 4. The results of the analysis from Figure 4 show that the distribution of the elements changed with the change in positions. These phases did not exhibit regular
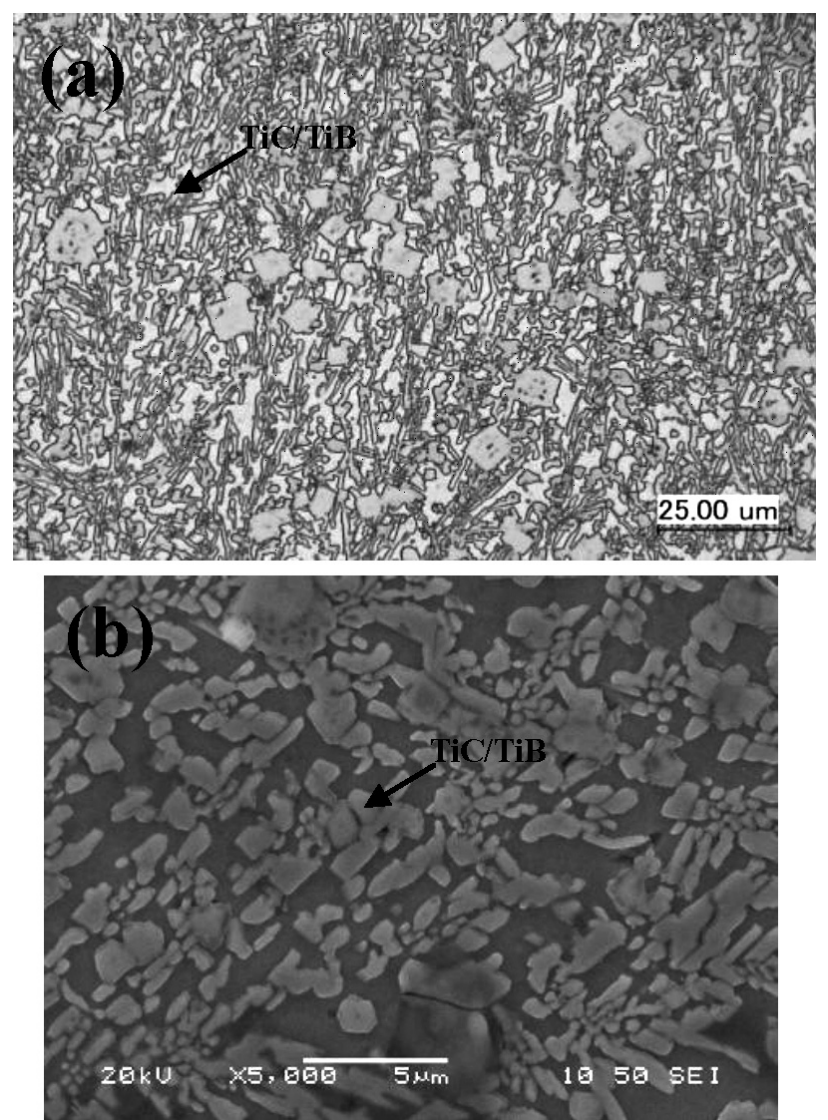

Figure 3: Microstructure of the transition zone of the composite coating: a) optical microscope and b) SEM image 


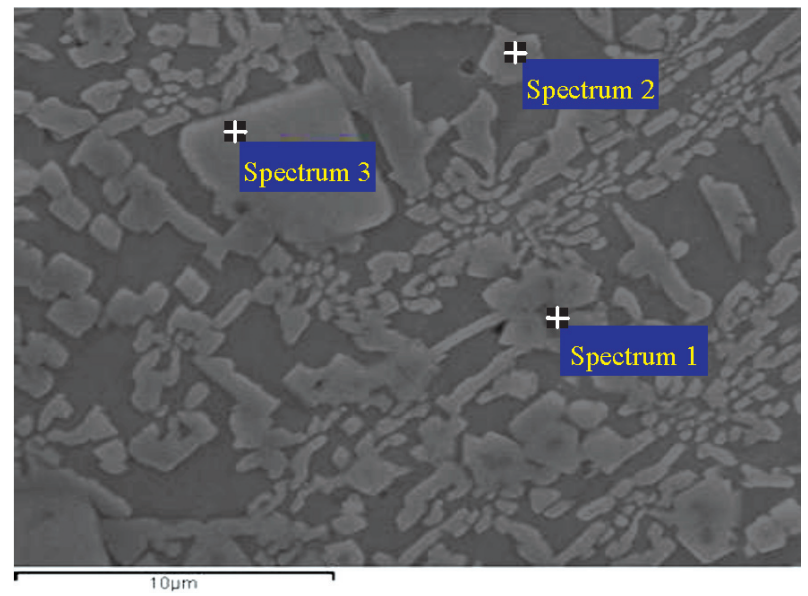

Figure 4: EDS point analysis of the composite coating and atomic content of the spectrometer marked at EDS points

\begin{tabular}{|c|c|c|c|c|c|c|}
\hline Element (\%) & C K & Ti K & Cr K & Fe K & Ni K & W M \\
\hline 1 & 43.44 & 18.41 & 2.53 & 16.98 & 7.22 & 29.61 \\
\hline 2 & 50.85 & 29.10 & 1.36 & 4.37 & 5.88 & 8.43 \\
\hline 3 & 31.24 & 1.95 & 19.22 & 25.88 & 7.87 & 13.83 \\
\hline
\end{tabular}

sizes and were scattered in the substrate. Most of them were carbides, as confirmed by the XRD analysis from Figure 1b. The two in-situ phase particles, namely, TiC and $\mathrm{TiB}$, solidified first and were entrapped by the other carbides because of the solidification. Parts of the particles were nucleated during the solidification. The composition of the particles was completely different, as shown in Figure 4.

\subsection{Vickers-hardness measurements}

The Vickers-hardness profile is shown in Figure 5. The Vickers hardness of the substrate was almost constant and roughly $150 \mathrm{HV}$. The hardness values of the coatings differed. In the case of the Stellite 6 coating, the value was $412 \mathrm{HV}$ and in the case of the composite

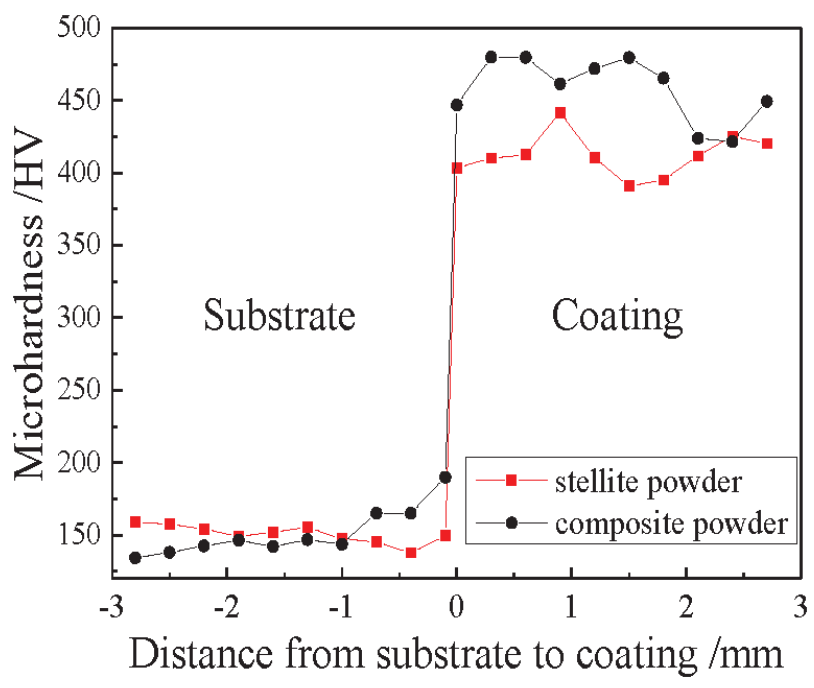

Figure 5: Distribution curve of the hardness coating, it was $458 \mathrm{HV}$. A sharp increase was observed because of the carbide in the coating. In the substrate, lower contents of $\mathrm{C}$ and hard cement components were observed compared with the contents of the coatings that used plasma arc welding, thereby showing a higher value of hardness. These components were kept stable in different structures, from the dilution zone to the grain zone, primarily due to the Stellite 6 coating. The hardness of the composite coating was better than that of the Stellite 6 alloy coating. This improved hardness was also related to the formation of boride and carbide in the alloy coating, which increased the hardness of the coating. The boride and carbide were $\mathrm{TiC}$ and $\mathrm{TiB}$, respectively. ${ }^{8,28,29}$ The structures of the coating differed from those of the Stellite 6 coating, as shown in Figures 3 and 4. The two phases enhanced the hardness of the composite coating.

\subsection{Friction coefficient and worn-out surface}

Figure 6a shows the friction coefficients of the Stellite 6 alloy and composite coatings. The average values of the friction coefficient of the coatings with Stellite 6 and composite powders were 0.7 and 0.56 , respectively. The run-to-join stage differed significantly. At this stage, the Stellite 6 coating used less time than the composite coating. This result coincides with the data on the wear rate, as shown in Figure 6b. The wear rates of the coatings with Stellite 6 and composite pow-
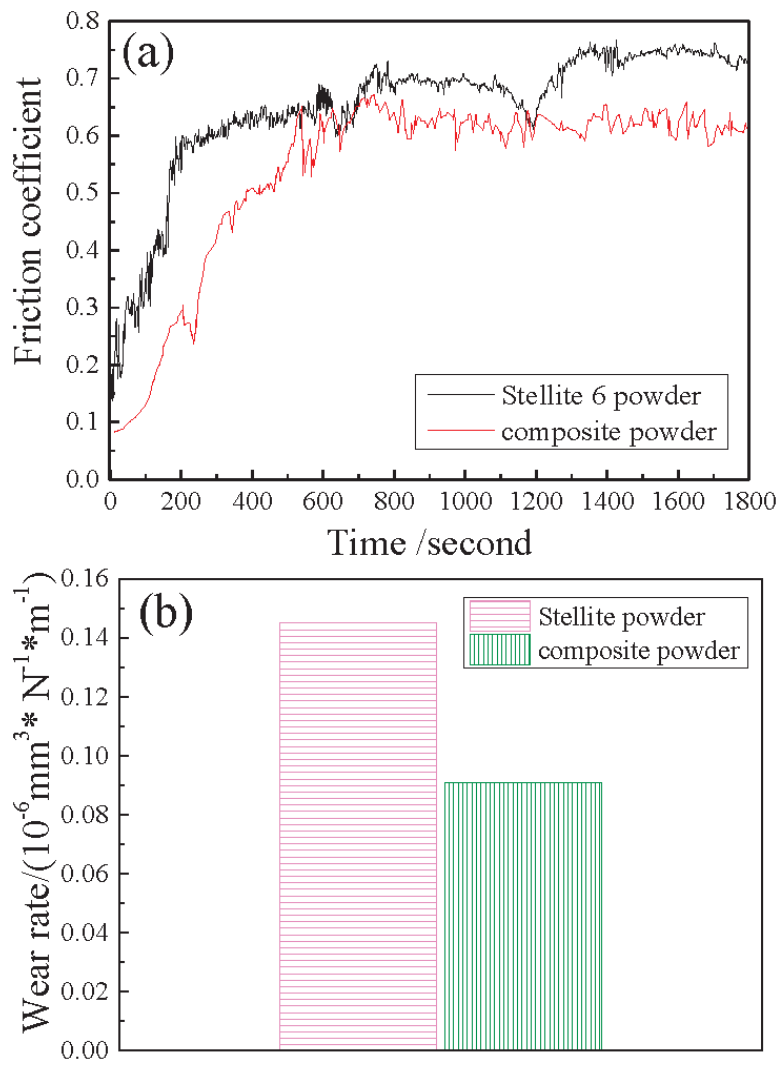

Figure 6: a) Friction coefficient of Stellite 6 and composite coating, b) wear rate of Stellite 6 and composite coating

Materiali in tehnologije / Materials and technology 53 (2019) 1, 3-8 

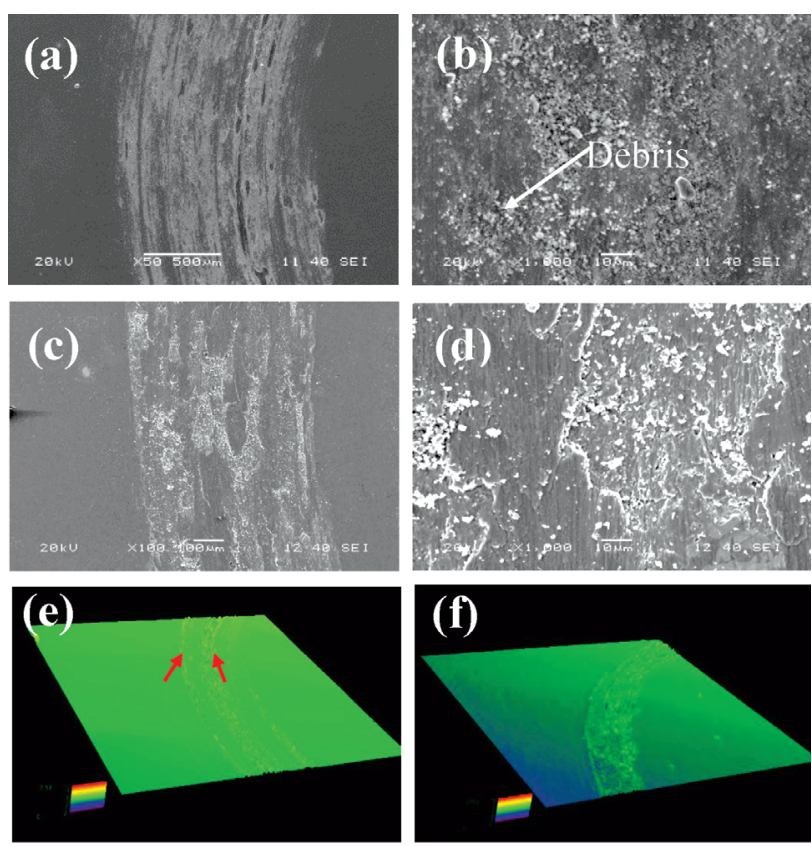

Figure 7: SEM images of coatings with different compositions after the wear and 3D morphology of different coatings after friction tests: a), b), e) Stellite 6 powder coating, c), d), f) composite powder coating

ders were $0.145 \times 10^{-6}$ and $0.091 \times 10^{-6} \mathrm{~mm}^{3} \mathrm{~N} \mathrm{~m} \mathrm{~s}^{-1}$, respectively. With a lower friction coefficient and wear rate, the composite coating showed better wear resistance than the Stellite 6 coating.

Figure 7 shows the wear tracks and delamination of different coatings. Figures $\mathbf{7 a}$ and $\mathbf{7 b}$ show the wear face of the Stellite 6 coating. Figures 7c and 7d present the wear surface of the composite coating. The surface wear was superficial and plastic deformation was limited. A comparison of Figures $\mathbf{7 b}$ and $\mathbf{7 d}$ shows that chunks of debris chipped away from the substrate, as shown by the red arrow in Figure $\mathbf{7 b} . \mathrm{M}_{7} \mathrm{C}_{3}$ was responsible for the debris. ${ }^{30}$ The carbide phase, $\mathrm{M}_{7} \mathrm{C}_{3}$, oxidised due to friction and cracked during the cyclic stress. These cracks led to a decrease in the adhesion strength between the coatings and caused the surface of the coating to delaminate. Debris was formed and chipped away from the coating. However, the coating with the composite powder had different particle sizes of hard phases TiB and $\mathrm{TiC}$, which improved the lubricity during the cyclic stress. The large white spots in Figure $\mathbf{7 d}$ contributed to lubricity. In Figures 7e and 7f, the depth of the wear surface is characterised with different colours. The Stellite 6 alloy coating showed a deep colour in Figure 7e (marked with red arrows) compared with the uniform colour in Figure 7f. Many uniform colour spots were observed and these included accumulated particles on the wear surface in Figure 7f. This finding is attributed to the removal of the second-phase particles of solidification, $\mathrm{TiC}$ and $\mathrm{TiB}$, during the sliding. The improvement in the wear resistance can be determined with these accumulated particles on the surface of the coating during the sliding. These particles reduced the friction coefficient of the composite coating, as shown in Figure 6a. The amount of wear was also reduced compared with the Stellite 6 coating. Therefore, sliding wear is the key mechanism of the composite alloy coating.

\section{CONCLUSIONS}

In this study, AISI 316 stainless steel specimens were used as a substrate and their surfaces were coated with Stellite 6 and composite powders (including Ti, $\mathrm{B}_{4} \mathrm{C}$ and Stellite 6) via PTAW. The results of the microstructure tests, EDS analysis, SEM, microhardness and wear tests of the coatings were discussed and the following conclusions were derived:

The microstructures of the samples showed that dendrites formed in the composite-powder-coated and Stellite-6-coated zones, and secondary phases of TiC and TiB were dispersed in the $\alpha$-Co solution in the composite coating.

The microhardness of the coating with composite powders increased by $11.2 \%$ and the friction coefficient and wear rate decreased by $20 \%$ and $37 \%$, respectively, relative to the values for the Stellite 6 powder coating. The wear resistance was improved due to the composite powders.

The accumulated particles of $\mathrm{TiC}$ and $\mathrm{TiB}$ were the result of the lubrication during the sliding. The sliding wear was the key mechanism of sliding.

\section{Acknowledgments}

The authors would like to express their sincere gratitude to the start-up project of Doctoral Scientific Research of Jiangsu University of Science and Technology (no. 1062921401) and the Science and Technology Program of the Jiangsu Province (nos. BE2015144 and BE2015145) for their financial support.

\section{REFERENCES}

${ }^{1}$ M. M. Ferozhkhan, M. Duraiselvam, K. G. Kumar, R. Ravibharath, Plasma transferred arc welding of Stellite 6 alloy on stainless steel for wear resistance, Procedia Technology, 25 (2016), 1305-11, doi:10.1016/j.protcy.2016.08.226

${ }^{2}$ A. Motallebzadeh, E. Atar, H. Cimenoglu, Sliding wear characteristics of molybdenum containing Stellite 12 coating at elevated temperatures, Tribology International, 91 (2015), 40-7, doi:10.1016/j.triboint.2015.06.006

${ }^{3}$ R. R. Bharath, R. Ramanathan, B. Sundararajan, P. B. Srinivasan, Optimization of process parameters for deposition of Stellite on $\mathrm{X} 45 \mathrm{CrSi} 93$ steel by plasma transferred arc technique, Materials and Design, 29 (2008), 1725-31, doi:10.1016/j.matdes.2008.03.020

${ }^{4}$ W. Ji, R. I. Todd, W. Wang, H. Wang, J. Zhang, Z. Fu, Transient liquid phase spark plasma sintering of B4C-based ceramics using Ti-Al intermetallics as sintering aid, Journal of the European Ceramic Society, 36 (2016), 2419-26, doi:10.1016/j.jeurceramsoc. 2016.03.028

${ }^{5}$ T. S. Sidhu, S. Prakash, R. D. Agrawal, Hot corrosion studies of HVOF NiCrBSi and Stellite-6 coatings on a Ni-based superalloy in an actual industrial environment of a coal fired boiler, Surface and 


\section{Z.-Y. ZHU et al.: MICROSTRUCTURE AND MECHANICAL PROPERTIES OF STELLITE 6 ALLOY POWDERS ...}

Coatings Technology, 201 (2006), 1602-12, doi:10.1016/j.surfcoat. 2006.02.047

${ }^{6} \mathrm{Q}$. Y. Hou, Microstructure and wear resistance of steel matrix composite coating reinforced by multiple ceramic particulates using SHS reaction of Al-TiO2-B2O3 system during plasma transferred arc overlay welding, Surface and Coatings Technology, 226 (2013), 113-22, doi:10.1016/j.surfcoat.2013.03.043

${ }^{7}$ J. Kaars, P. Mayr, K. Koppe, Generalized dynamic transition resistance in spot welding of aluminized 22MnB5, Materials and Design, 106 (2016), 139-45, doi:10.1016/j.matdes.2016.05.097

${ }^{8}$ G. Xu, M. Kutsuna, Z. Liu, L. Sun, Characteristic behaviours of clad layer by a multi-layer laser cladding with powder mixture of Stellite- 6 and tungsten carbide, Surface and Coatings Technology, 201 (2006), 3385-92, doi:10.1016/j.surfcoat.2006.07.210

${ }^{9}$ C.-R. Ciubotariu, D. Frunzăverde, G. Mărginean, V.-A. Serban, A.-V. Bîrdeanu, Optimization of the laser remelting process for HVOF-sprayed Stellite 6 wear resistant coatings, Optics and Laser Technology, 77 (2016), 98-103, doi:abs/2016OptLT..77...98C

${ }^{10} \mathrm{~S}$. Apay, B. Gulenc, Wear properties of AISI 1015 steel coated with Stellite 6 by microlaser welding, Materials and Design, 55 (2014), 1-8, doi:10.1016/j.matdes.2013.09.056

${ }^{11}$ B. Genc Oztoprak, E. Akman, M. M. Hanon, M. Günes, S. Gümüs, E. Kacar et al., Laser welding of copper with stellite 6 powder and investigation using LIBS technique, Optics and Laser Technology, 45 (2013), 748-55, doi:10.1016/j.optlastec.2012.05.001

${ }^{12}$ B. S. Sidhu, S. Prakash, Performance of NiCrAlY, Ni-Cr, Stellite-6 and $\mathrm{Ni3} \mathrm{Al}$ coatings in $\mathrm{Na}_{2} \mathrm{SO}_{4}-60 \%$ V2O5 environment at $900{ }^{\circ} \mathrm{C}$ under cyclic conditions, Surface and Coatings Technology, 201 (2006), 1643-54, doi:10.1016/j.surfcoat.2006.02.035

${ }^{13}$ C. Guoqing, F. Xuesong, W. Yanhui, L. Shan, Z. Wenlong, Microstructure and wear properties of nickel-based surfacing deposited by plasma transferred arc welding, Surface and Coatings Technology, 228 (2013), Supplement 1: S276-S82, doi:10.1016/j.surfcoat.2012. 05.125

${ }^{14} \mathrm{~S}$. Corujeira Gallo, N. Alam, R. O'Donnell, In-situ synthesis of titanium carbides in iron alloys using plasma transferred arc welding, Surface and Coatings Technology, 225 (2013), 79-84, doi:10.1016/ j.surfcoat.2013.03.019

${ }^{15}$ G. Zhang, C. S. Wu, Z. Liu, Experimental observation of both keyhole and its surrounding thermal field in plasma arc welding, International Journal of Heat and Mass Transfer, 70 (2014), 439-48, doi:10.1016/j.ijheatmasstransfer.2013.11.036

${ }^{16}$ M. Narimani, B. Lotfi, Z. Sadeghian, Evaluation of the microstructure and wear behaviour of $\mathrm{AA} 6063-\mathrm{B}_{4} \mathrm{C} / \mathrm{TiB}_{2}$ mono and hybrid composite layers produced by friction stir processing, Surface and Coatings Technology, 285 (2016), 1-10, doi:10.1016/j.surfcoat. 2015.11.015

${ }^{17}$ W. Xibao, W. Xiaofeng, S. Zhongquan, The composite Fe-Ti-B-C coatings by PTA powder surfacing process, Surface and Coatings Technology, 192 (2005), 257-62, doi:10.1016/j.surfcoat.2004.08.210

${ }^{18}$ J. F. Wang, Q. J. Sun, H. Wang, J. P. Liu, J. C. Feng, Effect of location on microstructure and mechanical properties of additive layer manufactured Inconel 625 using gas tungsten arc welding,
Materials Science and Engineering: A, 676 (2016), 395-405, doi:10.1016/j.msea.2016.09.015

${ }^{19}$ Q. Y. Hou, Z. Huang, J. T. Wang, Influence of nano-A12O3 particles on the microstructure and wear resistance of the nickel-based alloy coating deposited by plasma transferred arc overlay welding, Surface and Coatings Technology, 205 (2011), 2806-12, doi:10.1016/ j.surfcoat.2010.10.047

${ }^{20}$ F. Weng, H. Yu, C. Chen, J. Liu, L. Zhao, J. Dai et al., Effect of process parameters on the microstructure evolution and wear property of the laser cladding coatings on Ti-6Al-4V alloy, Journal of Alloys and Compounds, 692 (2017), 989-96, doi:10.1016/j.jallcom. 2016.09.071

${ }^{21} \mathrm{~J}$. Tang, Mechanical and tribological properties of the $\mathrm{TiC}-\mathrm{TiB}_{2} \mathrm{com}$ posite coating deposited on $40 \mathrm{Cr}$-steel by electro spark deposition, Applied Surface Science, 365 (2016), 202-8, doi:10.1016/j.apsusc. 2015.12.198

${ }^{22}$ R. Qin, G. He, Mass transfer of the nickel-base alloy covered electrode with neutral flux coating during shielded metal arc welding, International Journal of Heat and Mass Transfer, 78 (2014), 1095-104, doi:10.1016/j.ijheatmasstransfer.2014.07.074

${ }^{23}$ S. C. Gallo, N. Alam, R. O'Donnell, In-situ synthesis of titanium carbides in iron alloys using plasma transferred arc welding, Surface and Coatings Technology, 225 (2013), 79-84, doi:10.1016/j.surfcoat. 2013.03.019

${ }^{24}$ H. U. Jianjun, G. Chen, L. I. Shan, W. Zhou, Microstructure and properties of Ni-based alloy hardfacing prepared by plasma transferred arc welding, Hot Working Technology, (2013), doi:Article_en/ CJFDTOTAL-SJGY201303054.htm

${ }^{25}$ G. Chen, X. Fu, Y. Wei, L. Shan, W. Zhou, Microstructure and wear properties of nickel-based surfacing deposited by plasma transferred arc welding, Surface and Coatings Technology, 228 (2013), S276-S82, doi:10.1016/j.surfcoat.2012.05.125

${ }^{26}$ Z. Zhu, C. Ouyang, Y. Qiao et al., Wear characteristics of Stellite 6 alloy hardfacing layer by plasma arc surfacing processes, Scanning, (2017) 8, doi:10.1155/2017/6097486

${ }^{27}$ Z. Wang, J. Zhao, Y. Zhao et al., Microstructure and microhardness of laser metal deposition shaping K465/Stellite-6 laminated material, Metals - Open Access Metallurgy Journal, 7 (2017) 12, 512, doi:10.3390/met7110512

${ }^{28}$ G. Xu, M. Kutsuna, Z. Liu, K. Yamada, Comparison between diode laser and TIG cladding of Co-based alloys on the SUS403 stainless steel, Surface and Coatings Technology, 201 (2006), 1138-44, doi:10.1016/j.surfcoat.2006.01.040

${ }^{29}$ M. Ueno, N. Fujita, Y. Kimura, N. Nakata, Evaluation of coating and wear characteristics of roll surface coated with $\mathrm{TiC}$ by electrical discharge coating, Journal of Materials Processing Technology, 236 (2016), 9-15, doi:10.1016/j.jmatprotec.2016.04.025

${ }^{30}$ F. Luo, A. Cockburn, R. Lupoi, M. Sparkes, W. O’Neill, Performance comparison of Stellite 6® deposited on steel using supersonic laser deposition and laser cladding, Surface and Coatings Technology, 212 (2012), 119-27, doi:10.1016/j.surfcoat.2012.09.031 